\title{
IPTEKS AUDIT INTERNAL PADA PT. BANK SULUTGO MANADO
}

\author{
Feilen Grace Rondonuwu ${ }^{1}$, Fanda D.P. Rundengan ${ }^{2}$ \\ ${ }^{1,2}$ Jurusan Akuntansi, Fakultas Ekonomi dan Bisnis, Universitas Sam Ratulangi, Jl. Kampus Bahu, Manado, \\ 95115, Indonesia \\ E-mail : feilenrondonuwu@gmail.com
}

\begin{abstract}
Internal auditing or internal inspection is a part contained in a company that plays a role in an organization or company that functions to test and see how activities in an organization or company are carried out or carried out.According to Sukrisno Agoes in his book Auditing (examination of accountants) it was stated that: "Internal audit is an examination of the operations of a company, including accounting policies and operational policies that have been determined by management, to determine whether the operations have been carried out effectively, efficiently, and economical." The same applies to PT. Bank Sulutgo, the internal audit is carried out and carried out in accordance with the functions, duties / responsibilities and authorities that have been set by the bank / company, so that internal controls are carried out effectively and efficiently accompanied by high supervision procedures, to avoid deviations made by irresponsible party.
\end{abstract}

Keywords : internal audit, internal inspection

\section{PENDAHULUAN}

Pada jaman modern dan globalisasi yang sudah semakin maju ini, meskipun kebanyakan perusahaan sudah menggunakan alat elektronik yang canggih namun dalam organisasi di sebuah perusahaan tentunya masih sangat membutuhkan peran internal audit dalam mengevaluasi dan menilai kinerja pengendalian internal, disamping itu juga mampu mendukung kemajuan suatu perusahaan agar dapat bersaing dengan perusahaan lain di jaman yang semakin maju sekarang ini dengan temuan-temuan serta ide-ide yang membangun suatu perusahaan tentunya. Internal audit sangat diperlukan atau dibutuhkan pihak manajemen dalam sebuah perusahaan dalam menjalankan dan mengendalikan kegiatan operasional dalam suatu perusahaan. Orang yang melaksanakan audit internal juga bisa dibilang sebagai auditor internal.

Auditor internal ini sering ditemui atau dijumpai pada perusahaan-perusahaan atau organisasi besar dimana perusahaan atau organisasi itu mempunyai banyak divisi atau bagian-bagian yang memiliki fungsi, tugas, dan wewenang yang berbeda-beda. Dalam rangka mempertahankan usaha Bank yang tetap berfokus pada visi dan misi Bank itu sendiri, Bank Sulutgo senantiasa memberikan pedoman dan landasan sesuai dengan visi dan misinya bagi Satuan Kerja Audit Intern (SKAI) yang merupakan bagian dari divisi Pengendalian Intern Bank Sulutgo, maka dalam hal ini Bank Sulutgo menerapkan Audit Internal Charter. Diharapkan dengan adanya Internal Audit Charter ini, Satuan Kerja Audit Intern (SKAI) mempunyai Pedoman dan Landasan operasional yang pastinya diharapkan dapat digunakan dan diterapkan sebagai dasar dan pedoman dalam melaksanakan dan menjalankan tugas-tugas yang ada di Bank Sulutgo yaitu tugas pengendalian dan pengawasan sesuai dengan fungsi, tugas dan wewenang guna mewujudkan system pengendalian intern yang efektif dan efisien didalam sebuah perusahaan. 


\section{TINJAUAN PUSTAKA}

Definisi Audit Internal. Audit Internal adalah suatu bagian yang terdapat dalam suatu perusahaan yang berperan dalam organisasi atau perusahaan yang berfungsi sebagai pemeriksa untuk menguji dan melihat bagaimana catatan laporan keuangan dalam suatu perusahaan, serta melihat dan mengawasi apakah kegiatan dalam suatu perusahaan atau organisasi sudah dilaksanakan atau dijalankan secara efektif dan efisien sesuai dengan peraturan-peraturan yang ada dalam sebuah perusahaan serta ketentuan-ketentuan yang berlaku di dalamnya.

Fungsi dan Tujuan Internal Auditing. Dalam melaksanakan tugasnya, Internal Audit mempunyai beberapa fungsi dan tujuan, diantaranya adalah:

1. Melakukan penilaian dan pengawasan terhadap pelaksanaan system operasional akuntansi keuangan.

2. Menilai dan mengevaluasi kembali apakah penerapan pelaksanaan internal auditing sudah dijalankan sesuai dengan peraturan dan ketentuan yang di tetapkan.

3. Melihat dan memastikan serta melakukan control terhadap asset atau kekayaan perusahaan apakah sudah dijaga dan diawasi dengan baik dan aman guna mengantisipasi atau menghindari dari segala resiko kerugian yang nantinya terjadi.

4. Senantiasa meningkatkan kepercayaan operasional akuntansi dalam sebuah organisasi.

5. Menilai, menimbang dan mengevaluasi apakah pelaksanaan tugas dan tanggung jawab dalam perusahaan yang diberikan telah dijalankan sesuai dengan peraturan dan sebagaimana seharusnya dilaksanakan.

Dari penjelasan di atas, dapat diambil kesimpulan, bahwasannya tujuan dan fungsi dari internal auditing adalah untuk memberikan atau menerapkan pemeriksaan intern yang terstruktur dan jelas dalam membantu anggota manajemen di dalam perusahaan atau organisasi dalam melaksanakan tugasnya agar berjalan dengan efektif serta menyiapkan data yang akurat serta objektif dalam menganalisa, menilai, merekomendasikan, dan mengomentari aktivitas atau hasil yang dianalisa sebelumnya. Oleh karena itu internal auditing tetap harus mengawasi dan melihat tahap yang dijalankan dari kegiatan dalam sebuah perusahaan, agar internal audit itu sendiri dapat memberikan jasa atau kinerjanya dalam rangka mengembangkan serta mempertahankan tujuan perusahaan. Dalam melaksanakan tugasnya, Internal Auditing mempunyai beberapa tujuan yang dikemukakan oleh para ahli, diantaranya adalah:

1. Internal audit bertugas untuk membantu pihak manajemen guna mendapatkan administrasi perusahaan yang paling efektif dan efisien.

2. Menilai, menentukan dan memeriksa kebenaran dari data operasional keuangan yang dibuat dan melihat apakah efektif jika dibandingkan dengan intern prosedur.

3. Menilai dan memperbaiki apabila terdapat pekerjaan yang dijalankan tidak efisien dan efektif.

4. Membuat rencana ulang, atau susunan perubahan kembali jika diperlukan.

5. Mengawasi dan melihat apakah terdapat kecurangan yang menyangkutpautkan asset dalam sebuah perusahaan.

6. Menentukan dan menjalankan kerja sama dengan pihak manajemen, dalam rangka penerapan audit internal

Posisi Internal Auditor di dalam suatu Struktur Organisasi. Dalam suatu struktur organisasi di dalam sebuah perusahaan, terdapat beberapa alternatif kedudukan Internal Auditor, yaitu :

1. Berada di bawah Dewan Komisaris. Audit internal dalam hal ini mempunyai tugas pertanggungjawaban kepada Dewan Komisaris. Hal ini dikarenakan didalam sebuah perusahaan diperlukan sebuah pertanggung jawaban yang besar. Dalam hal ini, bagian system pengendalian intern sebenarnya merupakan suatu alat yang menjembatani 
performa manajemen yang pada hakikatya dikontrol langsung oleh komisaris perusahaan. Dengan demikian dapat disimpulkan bahwa bagian pemeriksaan intern mempunyai posisi yang kuat dalam sebuah organisasi atau perusahaan.

2. Berada di bawah Direktur Utama. Dalam system ini, audit internal bertanggung jawab pada DirUt. Namun, kebanyakan pada umunya sistem ini biasanya kurang atau jarang digunakan dalam perusahaan karena mengingat DirUt terlalu sibuk dengan tugastugasnya. Jadi bukan tidak mungkin jika tidak akan sempat dalam melihat atau mempelajari laporan yang dibuat oleh internal auditor.

3. Berada di bawah Kepala Bagian Keuangan. Internal auditor dalam hal ini mempunyai peran dalam struktur organisasi perusahaan yang berada dibawah naungan kepala bagian keuangan. Dalam bagian ini Internal auditor mempunyai tugas dan tanggungjawab kepada kepala keuangan atau sering juga disebut sebagai Controller. Namun, perlu kita ketahui bahwa biasanya pada umumnya kepala bagian keuangan juga mempunyai tugas dan tanggung jawab pada masalah akuntansi dan keuangan.

Laporan Internal Auditor. Laporan internal auditor adalah merupakan sarana atau tempat dimana auditor melakukan tanggung jawab atas tugas yang diberikan oleh pimpinan. Internal auditor melalui laporan ini akan memaparkan, melaporkan dan mengungkapkan kelemahan ataupun kecurangan yang terjadi serta keberhasilan didalam sebuah perusahaan.

1. Pemeriksaan. Dalam rangka pembuatan laporan, internal auditor terlebih dahulu harus melaksanakan pemeriksaan terhadap bagian yang akan diperiksa. Internal auditor dalam melaksanakan tugasnya terlebih dahulu harus menyusun rencana kerja pemeriksaan yang sudah disetujui sebelumnya oleh pimpinan perusahaan. Dari rencana kerja pemeriksaan yang telah disusun dan disetujui oleh Pimpinan perusahaan atau Direksi atau berdasarkan dengan informasi yang didapat atau diperoleh baik dari dalam maupun dari luar tentang adanya atau terdapat suatu penyelewengan yang mengarah pada kerugian perusahaan, maka internal auditing (auditor) harus dan wajib untuk mengadakan atau memberikan usulan pemeriksaan kepada manajemen. Dalam usulan pemeriksaan tersebut, pihak internal auditing sebaiknya dan semestinya memberikan pertimbangan-pertimbangan serta masukan-masukan yang beralasan, serta mampu menjadi dasar usulan pemeriksaan yang dapat dilakukan atau dipertanggungjawabkan. Disamping itu juga setiap usulan pemeriksaan atau masukan yang diberikan harus dapat atau mampu memberikan gambaran pada pihak manajemen berapa besar atau banyaknya biaya serta waktu yang diperlukan serta susunan-susunan auditor yang hendak akan mengikuti atau menjalankan tugas tersebut. Sebagai acuan dalam melaksanakan suatu pemeriksaan, dalam hal ini internal auditor harus memperoleh atau mempunyai surat penugasan yang dibuat oleh Direksi atau yang bertanggung jawab dalam hal itu. Surat penugasan itu sendiri adalah merupakan bukti dimana pihak Direksi menyetujui untuk melakukan atau menjalankan tugas dalam hal pemeriksaan serta pengawasan dan bahwa program pemeriksaan itu bisa atau dapat dijalankan atau dilaksanakan. Agar kegiatan di lapangan dapat terlaksana dengan baik dan berjalan dengan lancar, tentunya perlu adanya persiapan yang matang, yaitu, sebagai berikut: (a) mengumpulkan infromasi atau data yang merupakan dasar dari sebuah pemeriksaan; (b) menyiapkan kertas kerja pemeriksaan (working paper), working paper ini sendiri merupakan alat yang bisa digunakan untuk keperluan menghimpun data oleh staf internal auditing; (c) menyusun rencana pemeriksaan program audit, agar internal audit bisa mengetahui langkah-langkah apa yang nantinya harus dilakukan atau diambil; dan (d) mempersiapkan dengan matang dan baik peralatan lain yang nantinya pasti dibutuhkan dalam membantu kelancaran jalannya pemeriksaan.

2. Laporan. Setelah selesai melakukan pemeriksaan, selanjutnya internal auditor menyusun laporan dan diberikan kepada pihak manajemen. Agar laporan internal dari pihak auditor jelas dan juga terstruktur, maka perlu diperhatikan beberapa point yang menjadi fokus 
dalam pembuatan laporan. Pada point tiga 3 norma pelopor yang disusun atau dibuat oleh Bapeka. Menurut "Norma Pemeriksaan dan Tanggung Jawab Keuangan Negara" disebutkan:

Tiap laporan harus :

a. Memberikan/menyertakan atau menerangkan dengan jelas apa tujuan serta manfaat dari adanya atau dilakukannya pemeriksaan.

b. Dibuat seringkas mungkin dan jelas. Tiap laporan dibuat seringkas mungkin serta jelas agar mudah dimengerti/dipahami dan ditarik kesimpulannya oleh pihak yang menggunakan.

c. Manyajikan atau menyertakan kebenaran atau fakta-fakta dengan jelas dan teliti, apabila di dalamnya terdapat kesalahan penyelewengan atau penyimpangan sekiranya dapat dijelaskan mengapa sampai terjadi demikian.

d. Memberikan/menyertakan kesimpulan, saran dan pendapat yang mudah dimengerti dan dipahami serta dapat diterima secara objektif.

e. Membuat atau memberikan informasi berdasarkan fakta yang disertai dengan bukti pendukung yang dapat dipercaya dan dapat diterima.

f. Selalu membuat rencana pemeriksaan sebagai dasar pengambilan keputusan.

g. Fokus menjalankan point-point utama dalam hal perbaikan.

Dalam menyajikan laporan dalam bentuk tertulis, internal audit dalam hal ini harus menimbang dan melihat $10 \mathrm{C}$ prinsip penyajian, agar auditor dapat dengan mudah didalam menyusun sebuah laporan. Prinsip-prinsip tersebut adalah:

a. Correct, penyajian harus benar dan tepat.

b. Complete, penyajian harus menyeluruh atau secara lengkap.

c. Concise, penyajian dilakukan ringkas/singkat.

d. Clear, penyajian informasi harus disampaikan secara lugas dan tegas atau jelas.

e. Comprehensive, penyajian laporan harus bersifat luas atau meliputi banyak hal/menyeluruh.

f. Comperative, penyajian laporan harus diperbandingkan atau ditimbang kembali.

g. Conciderate, penyajian informasi harus relevan.

h. Celerity, penyajian laporan harus cepat atau selesai tepat waktu.

i. Candid, penyajian laporan harus berdasarkan fakta yang objektif.

j. Coordinate, laporan harus dapat dikoordinasikan atau disesuaikan dengan laporan yang lain.

\section{METODE DAN TEKNIK PENERAPAN IPTEKS}

\subsection{Metode Penerapan Ipteks}

Metode ipteks yang diterapkan yaitu mengevaluasi penerapan audit internal sesuai dengan Pedoman Audit Intern Berbasis Resiko (Risk Based Audit) PT. Bank Sulutgo

\subsection{Teknik Penerapan Ipteks}

Teknik IPTEKS yang diterapkan yaitu melakukan perbandingan antara penerapan audit internal pada PT Bank Sulutgo manado dengan penerapan audit menurut OJK.

\section{PEMBAHASAN}

\subsection{Gambaran Objek Penerapan Ipteks}

Fungsi Satuan Kerja Audit Internal. Fungsi Satuan Kerja Audit Internal (SKAI) yaitu melakukan evaluasi dan senantiasa terus berperan dalam peningkatan keefektivan pengendalian intern dan dalam rangka menjalankan tugas operasional Bank secara efektif dan efisien guna mencapai ketentuan yang sudah ditetapkan.

\section{Tujuan}

a. Melakukan penilaian secara independen terhadap kecukupan dan daya guna sistem 
pengendalian intern pada semua aktifitas Bank Sulut

b. Secara efektif membantu mewujudkan penerapan manajemen resiko dan prinsip kehatihatian secara efektif pada Bank Sulut.

c. Membantu manajemen dalam mewujudkan good corporate governance di lingkungan Bank Sulut.

Fungsi dan Penerapan Audit Intern. Dalam hal ini, Satuan Kerja Audit Intern (SKAI) mempunyai tanggung jawab atau bertanggung jawab kepada Direktur Utama dengan tugas utamanya adalah mengawasi dan terus mendukung terlaksananya internal control serta proses manejemen risiko di dalam suatu perusahaan. Dengan adanya internal kontrol yang baik, dari situ dapat dilihat apakah proses pengerjaan suatu pekerjaan dalam sebuah perusahaan sudah dijalankan atau berjalan dengan baik atau masih perlu adanya perbaikan berkelanjutan. Namun, sejauh ini dilihat dari hasil system pengendalian intern setidaknya sudah menunjukkan hasil yang baik, meskipun memang masih perlu adanya peningkatan kualitas secara keseluruhan. Dalam hal ini, Bank SulutGo terus berusaha agar sistem pengendalian intern bisa terus dijalankan sebagaimana diharapkan dan tetap berfokus pada peraturan, ketetapan atau ketentuan yang sudah disepakati bersama, serta menjalankan segala sesuatunya secara efektif dan efisien, serta senantiasa melihat dan menimbang apakah pengawasan sudah dijalankan dengan baik dan benar tanpa adanya kesalahan, dan juga senantiasa terus mengembangkan dan mempertahankan area atau lingkungan kerja yang menunjang dan membangun guna peningkatan upaya pengendalian intern. Pada tahun sebelumnya, ada pula kasus-kasus penyimpangan yang terjadi tepatnya selama tahun 2017 hal itu, sebagian besar disebabkan karena kurangnya pengawasan yang ketat dari pihak intern dalam mengawasi pejabat-pejabat atau karyawan yang ada dalam sebuah perusahaan yang mulai melakukan tindakan kecurangan atau penyimpangan dari peraturan-peraturan yang sudah disepakati sebelumnya, serta sering dijumpai kurangnya pemahaman dan kesadaran terhadap pentingnya menjaga prinsip konsistensi, kejujuran dalam melaksanakan sebuah pekerjaan. Agar menghindari terjadinya kembali hal-hal yang demikian, unit internal dalam perusahaan atau SKAI sebaiknya lebih meningkatkan serta terus memberikan pengawasan terhadap kecurangan-kecurangan yang kemungkinan terjadi. Unit SKAI berperan dalam mengutus mengikutsertakan auditornya atau karyawannya dalam pelaksanaan program pelatihan baik itu intern maupun ekstern, baik itu dalam hal seminar/workshop pelatihan, ataupun dalam hal mengikutsertakan auditor atau karyawan untuk mengikuti program berkaitan dengan tugas dari audit internal itu sendiri. 
Perbandingan Penerapan Tugas/Tanggung Jawab dan Wewenang Audit Internal Pada Otoritas Jasa Keuangan dan pada PT.Bank Sulutgo

\section{PT. BANK SULUTGO}

Tugas \& Tanggung Jawab

a. Menyusun program kerja audit setiap tahun berdasarkan resiko dan memberikan laporan mengenai hasil setiap Triwulan kepada Dewan Komisaris dan Dir Ut.

b. Menjalankan audit sesuai dengan rencana yang sudah ditetapkan pada setiap tahunnya, yang pastinya sudah disetujui oleh DirUt dan Dewan Komisaris.

c. Mempersiapkan audit cadangan yang menyelaraskan dengan permintaan dari pihak intern dan ekstern yang sudah disetujui oleh Direktur Utama Bank Sulutgo.

d. Melaksanakan audit (tujuan tertentu atas investigasi) jika didapati terjadinya indikasi kecurangan dalam sebuah perusahaan sesuai permintaan Direksi,atau Dewan Komisaris untuk menindaklanjuti.

e. Menyampaikan laporan pemeriksaan hasil audit internal kepada pimpinan Bank Sulutgo didalamnya tembusan dari Direktur Kepatuhan, kepada DirUt dan Dewan Komisaris

f. Menyampaikan laporan mengenai hasil audit pihak ektern dan intern kepada DirUt dan Dewan Komisaris dengan tembusan dari Direktur Kepatuhan

g. Melaksanakan pengawasan dan evaluasi terhadap temuan audit internal serta menyampaikan saran perbaikan sesuai system, kebijakan, peraturan dan regulasi yang berlaku.

\section{Wewenang}

a. Melaksanakan pemeriksaan tanpa pengecualian terhadap informasi karyawan, asset, catatan dan sumber dana/daya Bank Sulutgo yang berkaitan dengan plaksanaan audit Internal.

b. Meminta ijin/persetujuan serta melakukan komunikasi, kepada Dewan Komisaris dan Direksi untuk mendapatkan dukungan serta informasi yang diperlukan kedepannnya guna berjalannya pelaksanaan audit.

c. Meminta kerjasama atau bantuan dari divisi lain apabila diperlukan.

d. Meminta bukti pertanggung jawaban audit terhadap hasil atau penyelesaian dari sebuah pekerjaan, serta selalu melaksanakan investigasi.

\section{OTORITAS JASA KEUANGAN}

Tugas \& Tanggung Jawab

a. Menyusun rencana audit yang akan dilaksanakan setiap tahunnya;

b. Memeriksa dan memastikan kembali apakah pengendalian internal sudah dijalankan sesuai dengan paraturan perusahaan;

c. Memeriksa dan memastikan apakah dalam hal operasional keuangan, akuntansi, SDM, TI\&Ops, pemasaran dll sudah melaksanakan tugasnya secara efisien dan efektif;

d. Memberikan masukan atau saran mengenai kegiatan yang sudah dilaksanakan sebelumnya oleh phak manajemen;

e. Membuat dan menyimpukan laporan pemeriksaan hasil audit dan memberikannya kepada Dewan Komisaris dan Direktus Utama untuk diperiksa.

f. Melakukan tahap pemeriksaan atau penganalisahan mengenai laporan disarankan yang sudah diperbaiki sebelumnya;

g. Melaksanakan kerja sama dengan pihak Komite Audit guna mencapai system pengendalian intern yang efisien.

h. Membuat dan menyarankan program usulan untuk dijalankan guna melihat kinerja audit internal yang sudah dijalankan sebelumnya;

i. Melaksanakan pemeriksaan berkelanjutan apabila dibutuhkan guna menghindari kecurangan.

\section{Wewenang}

a. Melihat dan mengevaluasi informasi dengan pihak ekstern guna membandingkan tugas dan fungsi dari pihak intern;

b. Mengadakan komunikasi langsung dengan pihak pimpinan perusahaan, Direksi, Dewan Komisaris;

c. Melasanakan rapat yang berkelanjutan dengan pihak pimpinan perusahaan;

d. Menjalin informasi yang baik dengan auditor eksternal, guna saling berkoordinasi masing-masing kegiatan yang dijalankan. 


\section{KESIMPULAN DAN SARAN}

\subsection{Kesimpulan}

Audit internal adalah suatu bagian yang terdapat dalam suatu perusahaan yang berperan dalam organisasi atau perusahaan yang berfungsi untuk menguji dan melihat bagaimana kegiatan dalam suatu organisasi atau perusahaan dilaksanakan atau dijalankan. Tujuan audit internal membantu pihak manajemen guna memperoleh data administrasi dari perusahaan yang paling efektif dan efisien dengan menyertakan atau memuat kebijakan kebijaksanaan operasi kerja perusahaan.Dalam penerapannya Audit Internal mempunyai beberapa fungsi/tujuan, dan wewenang yang harus dijalankan/dilaksanakan secara efektif dan efisien serta harus memperhatikan tujuan dari audit internal itu sendiri. Dalam hal ini, Bank SulutGo terus berupaya agar sistem pengendalian intern dapat terus dijalankan sebagaimana mestinya yang tetap berfokus pada peraturan, ketetapan atau ketentuan yang sudah disepakati bersama, serta menjalankan segala sesuatunya secara efektif dan efisien, serta senantiasa melihat dan menimbang apakah prosedur pengawasan sudah dilaksanakan dengan baik dan benar tanpa adanya pengecualian, dan juga senantiasa terus mengembangkan dan mempertahankan lingkungan yang menunjang dan membangun guna peningkatan upaya pengendalian intern.

\subsection{Saran}

Dari pembahasan di atas dapat ditarik saran bahwa Bank harus tetap focus dan teliti dalam penerapan audit internal terhadap system pengendalian internal karena melihat dari kasus pada tahun sebelumnya, sebagian besar fraud disebabkan karena kurangnya pengawasan yang ketat dari pihak intern dalam mengawasi pejabat-pejabat atau karyawan yang ada dalam sebuah perusahaan yang mulai melakukan tindakan kecurangan atau penyimpangan, serta sering dijumpai kurangnya pemahaman dan kesadaran terhadap pentingnya menjaga prinsip konsistensi, kejujuran dalam melaksanakan sebuah pekerjaan. Agar menghindari terjadinya kembali hal-hal yang demikian, unit internal dalam perusahaan atau SKAI sebaiknya lebih meningkatkan serta terus memberikan pengawasan terhadap kecurangan-kecurangan yang kemungkinan terjadi. Unit SKAI sebaiknya berperan dalam mengutus atau mengikutsertakan auditornya atau karyawannya dalam pelaksanaan program pelatihan baik itu intern maupun ekstern, baik itu dalam hal seminar/workshop pelatihan, ataupun dalam hal mengikutsertakan auditor atau karyawan untuk mengikuti program berkaitan dengan tugas dari audit internal itu sendiri.

\section{DAFTAR PUSTAKA}

Nur apriyanti, Gevi. 2014. Pengaruh komitmen organisasi, locus of control, dan kompleksitas tugas terhadap kinerja auditor internal.

Kusnadi, I Made Gheby. Dan Dewa Gede Dharma Suputhra. 2015. Pengaruh profesionalisme dan locus of control Terhadap kinerja auditor internal.

Fanani, Zaenal. 2008. Pengaruh struktur audit, konflik peran dan ketidakjelasan peran terhadap kinerja auditor. Jurnal keuangan dan akuntansi Indonesia volume 5

Arens dan Loebbecke. 2003. Auditing Pendekatan Terpadu. Edisi Indonesia. Penerbit Salemba Empat, Jakarta.

David. C, Holmes, Burns, Arthur. W, Auditing Norma dan Prosedur 1998, Editor Sinaga Marianus, Penerbit Erlangga, Jakarta.

John B. Champbell and D. James. Wilson, Controllership, Tugas Akuntan Manajemen, Edisi Ketiga, Terjemahan Thia Tjin, H. Felix. Tjendra, Penerbit Erlangga, Jakarta.

Sukrisno. Agoes. 2004. (Petunjuk Praktis Pemeriksaan Oleh Akuntan Publik) Auditing. Edisi Ketiga. Salemba Empat: Jakarta. 
Dannag Sunyoto. 2013. (Pemeriksaan Akuntansi) Auditiing. Cetakan 1: (Center Off Academic Publishing Service) CAPS . Jakarta.

Tugiman, Hiroo. 2006. Standar Profesional Internal Audit. Cetakan ke-9. Kanisius: Jakarta. Statemeent on Auditing Statementt Net, Comite on Audiiting procedure 1973, AICPA, New York.

The Institute of Internal Auditor. 2016. Standar internasional praktik profesional Audit Internal

Megapratiwi. Silvia. 2015. Pengaruh role stress dan locus of control terhadap kinerja Auditor internal. 